DOI: $10.31073 / \mathrm{mivg} 201801-121$

Available (PDF): http://mivg.iwpim.com.ua/index.php/mivg/article/view/121

UDC 628.16:552.546

\title{
МЕТОДИКА ІНЖЕНЕРНИХ РОЗРАХУНКІВ БІОРЕАКТОРІВ ДЛЯ БІОЛОГІЧНОГО ОЧИЩЕННЯ ПРИРОДНИХ І ДООЧИЩЕННЯ СТІЧНИХ ВОД
}

\author{
П.Д. Хоружий ${ }^{1}$, док. техн. наук, С.Р. Стасюк 2 , Я.Б. Мосійчук ${ }^{3}$ \\ ${ }^{1}$ Інститут водних проблем і меліорації НААН Київ, Україна; e-mail: petro1939@bigmir.net \\ ${ }^{2}$ Тнститут водних проблем і меліорації НААН Київ, Україна; e-mail: sr-stasyuk@ukr.net \\ ${ }^{3}$ Інститут водних проблем і меліорації НААН Київ, Україна; е-mail: y.mosiichuk $(a)$ gmail.com
}

\begin{abstract}
Анотація. Проаналізовано систему біологічного очищення води з різними домішками в ній при прямоточному русі води через послідовно взаємодіючі споруди: біореактор (БР) - контактний прояснювальний фільтр (КІФ). Розроблена методика інженерних розрахунків БР для забезпечення прочесів насичення води киснем, видалення зоди газів та біохімічного окиснення домімок, що перебувають у вихідній воді, за допомогою мікроорганізмів, іммобілізованих на волокнистому фільтрувальному завантаженні.
\end{abstract}

Ключові слова: біореактор, біологічна плівка, волокнисте завантажения, концентрація субстрату, пористість завантаження, якість води

Постановка задачі. Для інтенсифікації процесів очистки природних і стічних вод у системах сільськогосподарського водопостачання і водовідведення запропоновано [1] низку заходів, одними з яких $€$ використання біологічних методів очищення води за допомогою прикріплених гідробіонтів у біореакторах 3 тонковолокнистим завантаженням, а також сил гравітації при висхідному русі скоагульованої води через плаваюче фільтрувальне завантаження

Уперше підняв питання про доцільність застосування мікробіологічних методів для очищення природних вод професор П.І. Гвоздяк [2], який стверджує, що мікробіологічним методом можна очистити будь-яку забруднену воду, значно підвищити ефективність очищення води, поліпшити якість очищеної води та зменшити їі собівартість.

Нині біологічні методи широко застосовуються для очищення природних і доочищення стічних вод [3-5]. При біологічному методі знезалізнення підземних вод специфічні залізобактерії Gallionella ferruginea завдяки своїй каталітичній дії швидко окиснюють $\mathrm{Fe}^{2+}$, a отриманий гідроксид заліза $\mathrm{Fe}(\mathrm{OH})_{3}$ накопичують у компактній формі, що значно збільшує брудомісткість КПФ і тривалість фільтроциклу.

Особливості роботи установки 3 БР $\mathrm{i}$ КПФ. Водоочисна установка для очищення природних або доочищення стічних вод (рис. 1) працюс так [6]. Вихідна вода по трубі 1-а через аератор 2 подається на БР 3 волокнистим завантаженням 4, що закрі- плюсться між колосниковими решітками 5. При розбризкуванні води в аераторі 2 на дрібні крапельки і падіння ї з висоти не менше 0,5 м вода насичується киснем, що використовується мікроорганізмами іммобілізованими на волокнистому завантаженні, для окиснення домішок, що знаходяться у вихідній воді.

БР виконує такі функції:

- біохімічне окиснення домішок, що перебувають у вихідній воді;

- видалення з води газів для виключення пухирцевої кольматації у підфільтровому просторі 8 КПФ;

- забезпечення постійної швидкості фільтрування води протягом фільтроциклу завдяки підвищенню рівня води в ньому при зміні втрат напору на КПФ від $h_{\phi .0}$ (при чистому завантаженні) до $h_{\text {p.max }}$ (у кінці фільтроциклу).

На КПФ 7 відбувається глибоке очищення води при ії висхідному русі через пінополістирольне завантаження 11. У підфільтровому просторі цього фільтра 8 накопичується осад 3 гідроксидної групи (при очистці природних вод) або активний мул (при доочищенні стічної води), який додатково бере участь в очищенні води, яка після висхідного фільтрування через пінополістирольне завантаження 11 збирається ковпачковим дренажем 12 і по трубопроводу 15 відводиться для подальшого використання.

Очищена вода відповідає нормативним показникам для фільтра даної конструкції і при даній швидкості фільтрування води $V_{\phi}$, коли питома брудомісткість КПФ знаходиться 
у межах між $G_{6 . \min }$ до $G_{6 \text { max }}$ Питомою брудомісткістю фільтра для даної швидкості фільтрування води називається кількість осаду, що припадає на $1 \mathbf{m}^{2}$ площі фільтра, кг/м².

При досягненні величини $G_{\text {б.max }}$ i відповідних їй втрат напору у завантаженні hф.max (рис. 1) КПФ необхідно промивати. Для цього закривають засувки 20, 22 і 24 та відкривають засувки 21 і 23. Промивна вода, рухаючись зверху вниз через пінополістирольне завантаження 11 вимиває 3 підфільтрового простору надлишок осаду $\Delta G=G_{6 \max }-G_{\sigma \text { min }}$ і виносить його через дренажну систему 9 і трубопровід 17 у каналізаційну трубу 18.

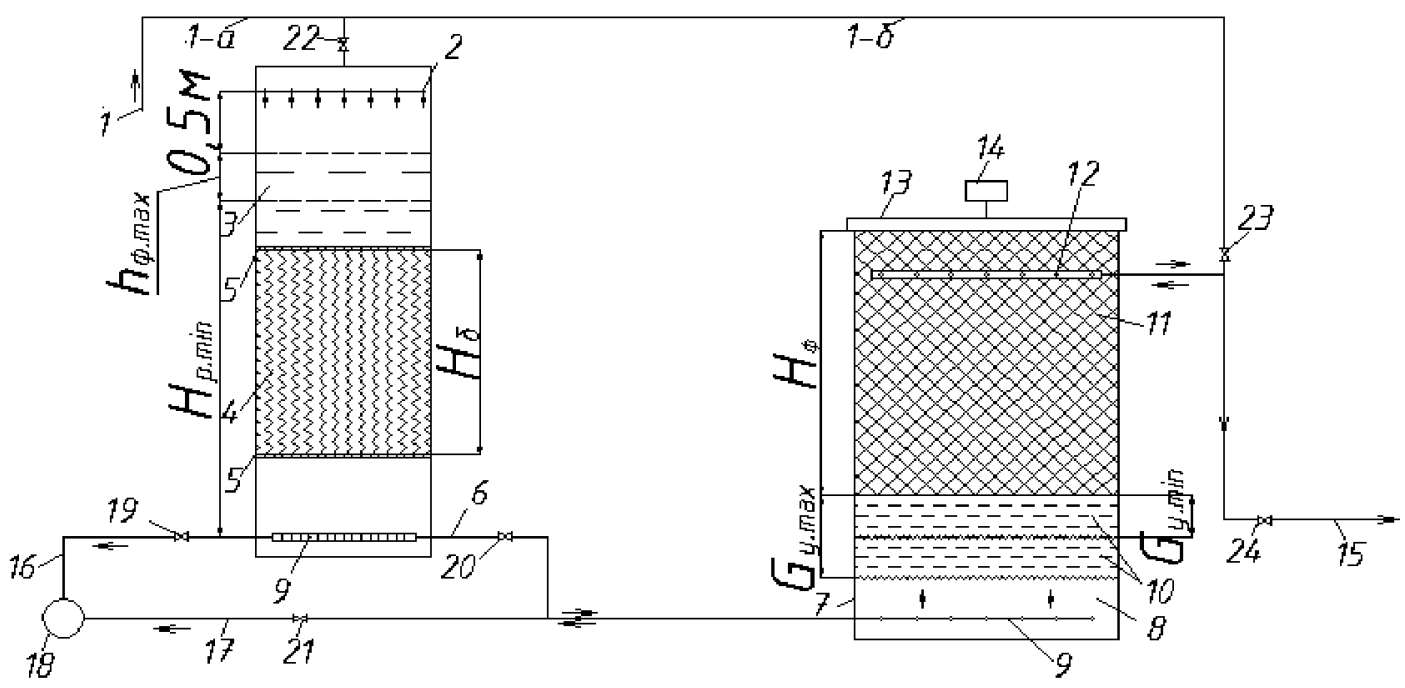

Рис. 1. Технологічна схема установки для очищення природних або доочищення стічних вод:

1 - подача вихідної води; 1-a-на БР; 1-б-для промивки КІІФ; 2 -аератор; 3 - БР;

4 - тонковолокнисте завантаження; 5 -колосникові решітки; 6-відеедення води на КПФ; 7 -КПФ;

8 - підфільтровий простір; 9 - дренажно-водорозподільча система; 10 - осад (активний мул);

11 - плаваюче пінополістирольне фільтрувальне завантаження; 12 - ковпачковий дренаж;

13 - кришка; 14 -вантуз; 15 - відведення очищеної води; 16 - скидання осаду при промивиі БР;

17 - те саме, при промивці КІФ; 18 -каналізаційна труба; $19-24$-засувки

Промивку КПФ з даною інтенсивністю $q_{n p}$ необхідно виконувати протягом розрахункового часу $t_{n p}$, щоб забезпечити нормативну якість фільтрованої води в наступному фільтроциклі його роботи.

Мета досліджень - розробити методику математичного моделювання процесів біологічного очищення природних $\mathrm{i}$ стічних вод на біореакторах та методи інженерних розрахунків цих споруд для визначення їх оптимальних конструктивних i технологічних параметрів.

Принцип роботи біореактора. Мікроорганізми, що населяють біоплівку, яка утворюється на поверхні ниток волокнистого завантаження, окиснюють речовини, що знаходяться у вихідній воді, киснем повітря, отримуючи при цьому енергію для своєї життєдіяльності (рис. 2).

Після інтенсивної аерації вихідна вода надходить в БР і рівномірно розподіляється між нитками волокнистого завантаження, обтікаючи їх поверхню на якій утворюється біоплівка 3 аеробними мікроорганізмами. Одночасно відбуваються такі процеси як адгезія, сорбція, дифузія, деструкція, окиснення тошо, унаслідок чого протікає швидке видалення речовин, що окиснюються, та утворення нових речовин [7-9].

Математична модель та алгоритм інженерних розрахунків БР. Для математичного описання процесів очищення води на БР потрібно встановити баланс зміни концентрації забруднень у біоплівці, рідкій плівці та об'ємі вихідної води, що знаходиться між волокнистими нитками та рухається в ньому зверху вниз (рис. 2).

Навколо кожної волокнистої нитки 1 діаметром $d_{n}$ утворюється біологічна плівка 2 товщиною $\delta_{n}$, а біля поверхні біоплівки утворюється тонкий ламінарний шар 3 (рідка плівка) товщиною $\delta_{p}$. 


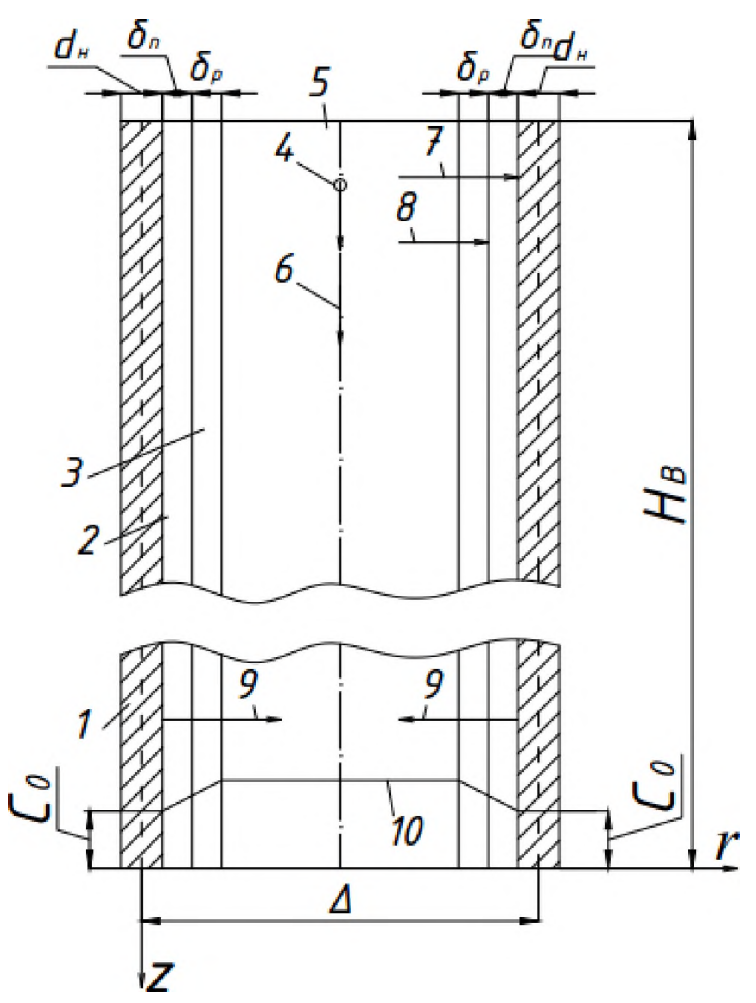

Рис. 2. Схема обміну речовин в елементарному шарі БР 3 волокнистим завантаженням:

1 - волокнисті нитки завантаження

2 біологічна плівка; 3 рідка плівка; 4 доміики у вихідній воді; 5 -вихідна вода; 6-напрялок руху води; 7 - надходження доміиюк до біоплівки 8 -надхооження кисню; 9 - видалення з біопивки продуктів біологічного очичення води:

10 - епюра розпооілу концентрачіі забруднень;

HB довжииа питок волокиистого заваита-

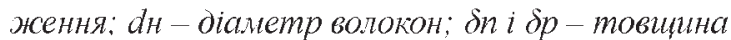
відповідно біоплівки і рідкої плівки; $\Delta$ - відстань між осяли ниток у волокнистому завантаженні

Площа біоплівки в 1 м БР визначається за формулою:

$$
F_{\sigma}=\pi d_{t} N, \mathrm{M}^{2} / \mathrm{M}
$$

де $N$ - кількість ниток завантаження в БР, яка залежить від форми його поперечного перерізу (рис. 3) і відстані між осями ниток у волокнистому завантаженні $\Delta$ :

Коефіцієнти упакування БР волокнами визначаються за формулами [11]:

а) для БР прямокутної форми

$\alpha=\frac{\omega_{H} N}{a b} \cdot \frac{(a-\Delta)}{\Delta} \frac{(b-\Delta)}{\Delta}=\frac{\omega_{H}}{a b} \cdot\left(\frac{a}{\Delta}-1\right)\left(\begin{array}{ll}\frac{b}{\Delta} & 1\end{array}\right)$

б) для БР квадратної форми

$\alpha=\frac{\omega_{H} N}{a^{2}}=\frac{\omega_{H}}{a^{2}} \cdot \frac{(a-\Delta)}{\Delta}=\omega_{H}\left(\frac{1}{\Delta}-\frac{1}{a}\right)^{2}$
A)

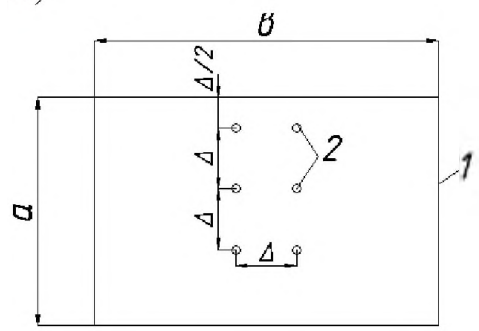

Б)

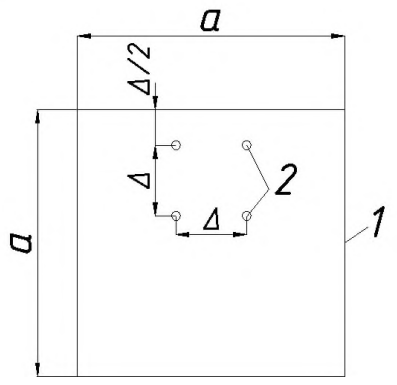

B)

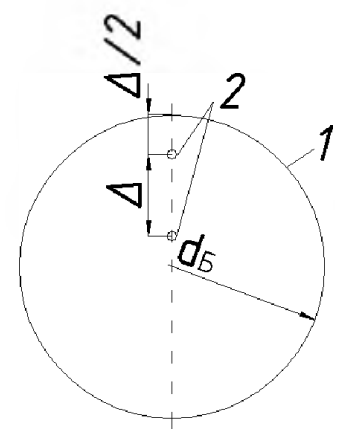

Рис. 3. Схеми рівномірного розміщення ниток волокнистого завантаження

в поперечному перерізі БР:

$A$ - пря.мокутної форми; 5 - квадратной форми; В ииліпдричиой форми; 1 корпус БР;

2 - нитки волокнистого завантаження

в) для БР циліндричної форми

$$
\alpha=\omega_{H}\left(\frac{1}{\Delta}-\frac{1}{d_{\sigma}}\right)^{2}
$$

У цих формулах: $a$ i 6 - розміри сторін поперечного перерізу БР прямокутної форми; $\underline{d}_{6}-$ діаметр БР циліндричної форми; $\Delta$ - відстань між осями ниток волокнистого завантаження; $\omega_{H}$ - площа поперечного перерізу однієї нитки; $N$ - кількість ниток у БР.

Пористість волокнистого завантаження визначається за формулою:

$$
P=1-\alpha
$$

У процесі фільтрування води пористість БР буде змінюватись за виразом

$$
P_{t}=1-\omega_{H t} / \Delta^{2}=P_{0}-\Delta P_{i},
$$


де $P_{0}$ і $P_{t}-$ пористість БР відповідно на початку фільтроциклу і через $t$ годин його роботи; $\Delta P_{t}-$ зменшення цієї пористості на момент часу $t$ унаслідок обростання ниток біоплівками; $\omega_{H t}$ - середня площа поперечного перерізу однієї нитки в цей момент.

Величина $\triangle \mathrm{Pt}$ визначається за формулою:

$$
\Delta P_{t}=\pi / 4\left(\delta_{n t} / \Delta\right)^{2},
$$

де $\delta_{n t}-$ товщина біологічної плівки навколо нитки на момент часу $t$.

Оскільки розміри БР: а, в і $d_{6}$ (рис. 3) значно більші величини $\Delta$, то після алгебраїчних перетворень площу біоплівки в 1 м БР можна визначати за формулою:

$$
F_{\sigma}=\frac{\pi d_{H} \omega_{\sigma}}{\Delta^{2}},
$$

де $\omega_{\sigma}$ - площа поперечного перерізу БР, м $^{2}$.

Потрібна кількість ниток в БР площею $\omega_{\sigma}$ 3 прийнятою відстанню між осями ниток $\Delta$ визначається за формулою:

$$
\mathrm{N}=\omega_{\bar{\sigma}} / \Delta^{2}
$$

або при відомій кількості ниток $\mathrm{N}$ середня відстань між їх осями мас бути:

$$
\Delta=\sqrt{\omega_{\sigma} / N}
$$

При складанні рівнянь матеріального балансу, записаних відносно концентрації забруднень, зміни яких відбуваються в БР, приймаються припущення, описані у спеціальній літературі $[6,7]$, що дало можливість отримати таку залежність:

$P \frac{\partial C}{\partial t}=-V_{\phi} \frac{\partial C_{e}}{\partial z}-\frac{K c F \sigma}{\omega_{\tilde{\sigma}}}\left(C_{e}-C_{\sigma}\right), \Gamma /\left(\right.$ дм ${ }^{3}$ год) (11)

де $V_{\phi}$ - швидкість фільтрування води в БР, м/год; $P$ - пористість фільтрувального завантаження БР; $C_{e}$ і $C_{6}$-концентрація субстрату у вихідній воді, відповідно у порових каналах

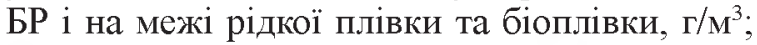
$\frac{\partial C}{\partial t}$ i $\frac{\partial C_{e}}{\partial z}-$ зміна концентрації субстрату, відповідно у часі та по шляху фільтрування води в БР; $K c$ - коефіцієнт масопереносу субстрату в рідкій плівці, м/год; $F_{\sigma}$ - загальна площа біоплівки БР висотою $1 \mathrm{M}, \mathrm{M}^{2} / \mathrm{M} ; \omega_{6}-$ площа поперечного перерізу БР, через яку рухається вихідна вода, $\mathbf{M}^{2}$.

Пористість волокнистого завантаження визначається за формулою (6), а площа біоплівки в 1 м БР - за формулою (8).

Отже, для БР 3 волокнистим фільтрувальним завантаженням можна записати:

$$
\left(1-\frac{\omega_{H} t}{\Lambda^{2}}\right) \frac{\partial C_{e}}{\partial z}-V_{\phi} \frac{\partial C_{e}}{\partial z} \frac{K_{e} F_{6}}{\omega_{\sigma}}\left(C_{e}-C_{6}\right), \Gamma /\left(\text { дм }{ }^{3} \text { год }\right)(12)
$$

У результаті розв'язання рівняння (12) відносно $C_{e}$ отримано залежність для визначення концентрації суб́страту по висоті фільтра $H_{\tilde{\sigma}}$ :

$$
C_{e(z, t)}=C_{0} e^{-\ddot{z}}
$$

де $C_{0}$ - концентрація субстрату у вихідній воді на вході в БР, $\Gamma / \mathbf{M}^{3} ;$ ž - параметр, який характеризує інтенсивність зміни концентрації субстрату на межі поділу плівок по висоті БР:

$$
\check{\mathrm{z}}=\mathrm{z} \frac{A_{0}}{V_{\phi}},
$$

де $A_{0}$ - параметр, що характеризує умови біосорбції в БР

$$
A_{0} \frac{K_{\varepsilon} \pi d_{u}}{\Delta^{2}}\left(1-\frac{C_{\sigma}}{C_{e}}\right), \text { год }^{-1}
$$

На виході з БР z $=H_{0}$. Тоді:

$$
\begin{gathered}
C_{\phi}=C_{0} e^{-\hat{H}_{0}} ; \\
H_{\sigma}=H_{\sigma} \frac{A_{0}}{V \phi}
\end{gathered}
$$

Записавши залежність (17) відносно $H_{6}$, отримаємо такі вирази для визначення необхідної висоти $H_{\tilde{\sigma}}$ Нб або при відомій величині $H_{6}$ для визначення якості води $C_{\phi}$, що виходить 3 БР:

$$
\begin{gathered}
H_{\sigma}=\frac{V_{\phi}}{A_{0}} \ln \frac{C_{0}}{C_{\phi}}, \mathrm{M} \\
C_{\phi}=C_{0} / \operatorname{expp} \frac{A_{0} H_{6}}{V_{\phi}}, \Gamma / \mathrm{M}^{3}
\end{gathered}
$$

Як бачимо з формули (18), необхідна робоча висота завантаження БР (рис.1) залежить від розрахункової глибини очищення води $C_{d} d C_{\phi}$, прямо пропорційна швидкості фільтрування води $V \phi$ і обернено пропорційна величині параметра $A_{0}$, що визначається за формулою (15), яка після перетворень має вигляд:

$$
A_{0}=A B, \text { год }^{-1}
$$

де $A$ - параметр, що характеризує процес масопереносу між волокнистими нитками БР:

$$
A=K c\left(1-\frac{C_{s}}{C_{e}}\right), \mathrm{м} / \text { год }
$$

$B$ - параметр, що характеризує геометричне середовище волокнистого завантаження і дорівнює відношенню довжини лінії навколо однієї нитки завантаження до квадрату відстані між їх осями:

$$
\mathrm{B}=\frac{\pi d_{u}}{\Delta^{2}}, \mathrm{M}^{-1}
$$


Отже, із збільшенням кількості ниток в одиниці об'єму волокнистого завантаження БР величина $\triangle$ буде зменшуватись, тобто параметри $B$ та $A_{0}$ будуть збільшуватись, а потрібна висота БР згідно з формулою (18) буде меншою.

Інженерні розрахунки БР. БР виконують роль повітровідокремлювачів, площу яких необхідно приймати 3 розрахунку швидкості руху низхідного потоку води не більше $0,05 \mathrm{M} / \mathrm{c}$ та тривалості перебування води в ньому не менше 1 хвилини [12].

Розрахунки ведуть у такій послідовності:

- для розрахункової витрати води через БР $\mathrm{Q}_{\mathrm{P}}, \mathrm{M}^{3} /$ год, прийнятої кількості ниток волокнистого завантаження $\mathrm{N}$ і площі поперечного перерізу однієї нитки $\omega_{H}$, визначаємо площу поперечного перерізу БР:

$$
\omega_{\sigma}=\frac{\mathrm{Q}_{\mathrm{P}}}{180}+N \omega_{h}, \mathrm{M}^{2}
$$

і швидкість руху води в БР:

$$
V \phi=Q_{P} / \omega_{6}, \text { м/год }
$$

- для забезпечення необхідного часу перебування води в БР тривалістю $t p \geq 1$ хв його висота повинна бути не меншою (рис. 1)

$$
H_{P, m i n} \geq \frac{Q_{P} t_{p}}{60 \omega_{6}}, \mathbf{M}
$$

При граничній швидкості руху води в БР $V_{\text {sp }}=0,05 \mathrm{M} / \mathrm{c}$ ця висота має бути не меншою $H_{P, \text { min }} \geq 3 \mathrm{M}$;
- для попередніх розрахунків приймаємо оріснтовні значення вихідних констант і коефіцієнтів, визначених у спеціальній літеpaтурі $[7,8]: K c=0,025-0,080$ м/год; $A=0,01-$ $0,04 \mathrm{M} /$ год; $\delta_{n}=0,1-0,2 \mathrm{Mм}$;

- визначаємо параметр В за формулою (22), параметр $A_{0}$ за формулою (20) та величину $H_{6}$ за формулою (18);

- за даними лабораторних досліджень знаходимо максимальну питому брудомісткість БР, тривалість фільтроциклу у зоні накопичення забруднень та тривалість промивки БР при даній ії інтенсивності;

- уточнюємо розрахункові величини $H_{6}$ i $C_{\phi}$ та ефективність очишення води на БР.

\section{Висновки.}

1. Необхідна робоча висота завантаження БР залежить від глибини очищення води $C_{0} / C_{\phi}$, прямо пропорційна швидкості фільтрування води $V_{\phi}$ i обернено пропорційна кількості ниток в одиниці завантаження БР.

2. Розроблена методика інженерних розрахунків БР дозволяє визначати їх раціональні конструктивні і технологічні параметри, виходячи з вимог забезпечення необхідного часу перебування води в БР при граничній швидкості низхідного руху води та розрахункової ефективності очищення води від домішок.

\section{Бібліографія}

1. Хоружсий П.Д., Хомутеиька Т.П., Хоружий В.П. Ресурсозберігаючі технологій водопостачання. Київ: Аграрна наука, 2008. 534 с.

2. Гвоздяк П.И. Микробиология и биотехнология очистки воды: Quо vadih // Химия и технология воды. 1989. №9. С. 854-858.

3. Grochmann A., Gollasch R., Chumacher G. Biologische enteisenung und entmanganung eines methanhaltigen grandwasser in speyir, GWF. Wasser, Abwasser. 1989. S. 441-447.

4. Badjo I., Mouches P. Technologies appropries. L'exemple d'une grande instullation de deferrasation biologique au Togo. - 38, № 3 - P. 197-206

5. Ковальчук В.А. Очистка стічних вод. Рівне: ВАТ «Рівненська друкарня», 2002. 622 c.

6. Патент на корисну модель № 122635. Станиія для біологічного очищення господарсько-побутових стічних вод/П.Д. Хоружий, Я.Б. Мосійчук. 2018.

7. Christiansen P., Hollesen L., Harremoes P. Liquid film diffusion of reaction rate in submergen biofilters. Wat.Res., 1995, vol. 29, №1. Pp. 947-952.

8. Henze M., Harremoes P., Jansen C., Arwin E. Wastewater Treatment Springer. Berlin, New York, 2002. $430 \mathrm{p}$.

9. Хоружий В.П. Кінетика висхідного фільтрування води на установках з волокнисто-пінополістирольним завантажсенням // Вісник інженерної академій України, №200. №2. С. 82-87.

10.Недаиківський І.П. Очистка господарсько-побутових стічних вод на фільтрах з волокнисто-пінопластовим завантаженням : Дисертація канд. техн. наук: 05.23.04, Одес. держ. акад. буд-ва та архітектури. Одеса: 2015. 200 c.

11. Котельчук А.Л. Обгрунтування технологї̈ підготовки господарсько-побутових стічних вод для використання їх в системах зроиення : Дисертація канд. техн. наук: 06.01.02, Інститут гідротехніки і меліорації УААН. Київ: 2008. 159 c. 
12.ДБН В.2.5-74:2013. Водопостачання. Зовнімин мережі та споруди. Київ: Мінрегіон України, 2013. $172 \mathrm{c}$.

\section{References}

1. Horuzhy, P.D., Khomutetska, T.P., \& Horuzhy, V.P. (2009). Resursozberihayuchi tekhnolohiyi vodopostachannya [Resource-saving water supply technologies]. Kyiv: Ahrarna nauka [in Ukrainian].

2. Gvozdyak, P.I. (1989). Mikrobiologiya i biotekhnologiya ochistki vody: Quo vadih [Microbiology and biotechnology of water purification: Quo vadih]. Khimiya i tekhnologiya vody - Chemistry and technology of water, 9, 854-858 [in Ukrainian].

3. Grochmann, A., Gollasch, R., \& Chumacher, G. (1989). Biologische enteisenung und entmanganung eines methanhaltigen grundwasser in Speyir [Biological de-icing and demanganization of methane-containing groundwater in Speyir]. GWF. Wasser, Abwasser - GWF. Water, Sewage, 441-447 [in German].

4. Badjo, I., \& Mouches, P. Technologies appropries. The exemple d'une grande instullation de deferrasation biologique au Togo. 38, 3, 197-206 [in English].

5. Kovalchuk, V.A. (2002). Ochystka stichnykh vod [Waste water treatment]. Rivne: VAT «Rivnens'ka drukarnya» [in Ukrainian].

6. Horuzhy, P.D., \& Mosiychuk, Ya.B. (2018). Patent na korysnu model' №122635. Stantsiya dlya biolohichnoho ochyshchennya hospodars'ko-pobutovykh stichnykh vod [Patent for Utility Model №122635. Station for biological treatment of household wastewater]. Kyiv: Derzhavna sluzhba intelektual noyi vlasnosti Ukrayiny [in Ukrainian].

7. Christiansen, P., Hollesen, L., \& Harremoes, P. (1995). Liquid film diffusion of reaction rate in submergen biofilters. Wat. Res., vol. 29, 1, 947-952 [in English].

8. Henze, M., Harremoes, P., Jansen, C., \& Arwin, E. (2002). Wastewater Treatment Springer. Berlin, New York [in English].

9. Horuzhy, V.P. (2004). Kinetyka vyskhidnoho fil truvannya vody na ustanovkakh z voloknysto-pinopolistyrol'nym zavantazhennyam /Kinetics of ascending filtering of water at installations with fiberfoam polystyrene loading]. Visnyk inzhenernoyi akademiyi Ukrayiny - Bulletin of the Engineering Academy of Ukraine, 2, 82-87 [in Ukrainian].

10. Nedashkivsky, I.P. (2015). Ochystka hospodars'ko-pobutovykh stichnykh vod na fil trakh z voloknysto-pinoplastovym zavantazhennyam [Cleaning of household sewage on filters with fiberfoam-type loading]. Candidate's thesis. Odessa: State Academy of Civil Engineering and Architecture [in Ukrainian].

11. Kotelchuk, A.L. (2008). Obgruntuvannya tekhnolohiyi pidhotovky hospodars'ko-pobutovykh stichnykh vod dlya vykorystannya yikh $v$ systemakh zroshennya [Substantiation of technology for the preparation of household sewage for their use in irrigation systems]. Candidate's thesis. Kyiv: Institute of Hydrotechnics and Land Reclamation of UAAS [in Ukrainian].

12. DBN V.2.5-74:2013. (2013). Vodopostachannya. Zovnishni merezhi ta sporudy [Water supply. External networks and facilities]. Kyiv: Minrehion Ukrayiny [in Ukrainian].

\section{Методика инженерных расчетов биореакторов для биологической очистки природных и доочистки сточных вод}

Проанализирована система биологической очистки воды с различными примесями в ней при прямоточном движении воды через последовательно взаимодействующие сооружения: биореактор (БР) - контактный осветлительный фильтр (КОФ). Разработана методика инюенерных расчетов БР для обеспечения прочессов насыщения воды кислородом, удаление из воды газов и биохимического окисления примесей, находящихся в исходной воде, с помочью микроорганизмов, иммобилизованных на волокнистой фильтровальной загрузке.

\section{Method of engineering calculations of bioreactors for biological treatment of natural water and advanced treatment of sewage}

The system «bioreactor (BR) - contact clarifying filter (CCF)» of biological water purification with various impurities in it in the case of direct water flow through successively interacting structures is analyzed. The method of engineering calculations of the BR that provides saturation of water with oxygen, gases removal from water, and biochemical oxidation of impurities present in the input water, with the help of microorganisms immobilized on fibrous filtering load, is developed. 